University of Chicago Law School

Chicago Unbound

Journal Articles

Faculty Scholarship

2008

Feminist Fundamentalism on the Frontier between Government and Family Responsibility for Children

Mary Anne Case

Follow this and additional works at: https://chicagounbound.uchicago.edu/journal_articles

Part of the Law Commons

Recommended Citation

Mary Anne Case, "Feminist Fundamentalism on the Frontier between Government and Family Responsibility for Children," 11 Journal of Law and Family Studies 333 (2008).

This Article is brought to you for free and open access by the Faculty Scholarship at Chicago Unbound. It has been accepted for inclusion in Journal Articles by an authorized administrator of Chicago Unbound. For more information, please contact unbound@law.uchicago.edu. 


\title{
FEMINIST FUNDAMENTALISM ON THE FRONTIER BETWEEN GOVERNMENT AND FAMILY RESPONSIBILITY FOR CHILDREN
}

\author{
Mary Anne Case*
}

TABLE OF CONTENTS

I. INTRODUCTION

II. SeX Equality Is a Particular as WELl AS A UNIVERSAL VALUE .............335

III. The U.S. SUPREME COURT'S ARTICULATION OF SEX EQUALITY

AS A PRIORITY

IV. FEMINIST FUNDAMENTALISM IN EDUCATIONAL PROGRAMS

* (C) 2009 Mary Anne Case, Arnold I. Shure Professor of Law, University of Chicago Law School. This paper is part of the author's broader project on Feminist Fundamentalism, which also includes, inter alia, a version published in WHAT IS RIGHT FOR CHILdREn?: THE COMPETING PARAdigms of RELIGion AND HuMAN Rights (Martha Albertson Fineman \& Karen Worthington eds., 2009); Mary Anne Case, Feminist Fundamentalism and Constitutional Citizenship, in DIMENSIONS OF WOMEN'S EQUAL CiTizenshiP (Joanna L. Grossman \& Linda C. McClain eds., 2009) [hereinafter Case, Constitutional Citizenship]; and Mary Anne Case, Feminist Fundamentalism and the Baby Markets, in BABY MARKETS: MONEY, MORALS AND THE NEOPOLITICS OF CHOICE (Michele Goodwin ed., forthcoming 2010) [hereinafter Case, Baby Markets]. Portions of this paper, and of the broader project, were presented at conferences on Competing Paradigms of Rights and Responsibility: Children in the Discourses of Religion and International Human Rights at the Emory School of Law; Baby Markets at De Paul Law School; Working From the World Up: Equality's Future at the University of Wisconsin; Women's Equal Citizenship at Hofstra Law School; Gender and Family Responsibility at the University of Sussex; The Road to Equality: Are We There Yet? at the Thomas M. Cooley Law School; and Constitutionalizing Women's Equality at the University of California, Berkeley; at Law and Society 2008 and LatCrit 2007; and at faculty colloquia at the law schools of the University of Alabama, Cornell, Georgetown, the University of Iowa, Rutgers Camden, Seton Hall, the University of North Carolina, and the University of Chicago as well as at the University of Chicago Gender and Sexuality Workshop and the Princeton University Program in Law and Public Affairs. I am grateful to organizers and participants in those events, particularly Amy Baehr, Ava Baron, Cynthia Bowman, Maxine Eichner, Martha Ertman, Martha Fineman, Jose Gabilondo, Joanna Grossman, Sally Goldfarb, Michele Goodwin, Dirk Hartog, Beth Hillman, David Hollander, Pnina Lahav, Jamie Mayerfeld, Linda McClain, Larry Rosen, Kim Lane Scheppele, Mike Seidman, Gerald Wetlaufer, Wibren van der Burg, and Viviana Zelizer; as well as to Emily Buss, Peggy Cooper Davis, Jim Dwyer, Chris Eisgruber, Robert George, Nan Keohane, Rachel Rebouche, Cliff Rosky, Cass Sunstein, Walter Wadlington and Deborah Widiss for their brainstorming help; to Jake Glazeski, Lyonette Louis-Jacques, Deborah Megdal and Margaret Schilt for their reference assistance; and to the Arnold and Frieda Shure Fund and Princeton University's Crane Fellowship in Law and Public Affairs for support.

$$
\begin{aligned}
& \text { 333-JLFS } \\
& \text { 381-ULR }
\end{aligned}
$$


V. Sex Equality in Educational Programs Is Linked to EQuality

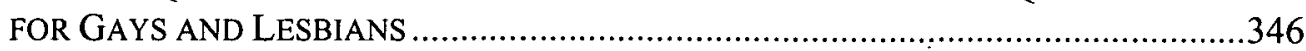

VI. FEMINIST FUNDAMENTALISM IN CHILD CUSTODY AND ADOPTION …….........348

VII. CONCLUSION: THE TEXAS FLDS CASE AS AN EXAMPLE OF HOW NOT TO APPLY THE DISCOURSES OF RELIGION AND HUMAN RIGHTS

TO CHILDREN.

\section{INTRODUCTION}

The equality of the sexes, and the instantiation of that equality in the repudiation of "fixed notions concerning the roles and abilities of males and females," are fundamental commitments on which all levels of government in the United States must follow through, not only in lawmaking, but in hortatory pronouncements, funding decisions, and necessary interventions into the family, such as child custody and adoption decisions. Not only in public schools and government funded educational programs, but in state-licensed private schools and home schooling, they must ensure that girls and boys receive equal opportunity. And evidence of commitment to sex equality should be at least as assiduously enquired into and at least as positively weighted as a prospective adoptive or custodial parent's commitment to providing a child with religious training, something many decision makers seem to enquire into and weigh favorably, often without much apparent attention to the substance of the religious beliefs.. As things now seem to stand, however, when repressive religious beliefs are pitted against secular feminist ones, the religious beliefs often seem to begin with a presumption to respect which is even more deserved by, but often not granted to, the feminist ones.

Therefore, at a time when so many different religious fundamentalisms are demanding legal recognition-particularly when it comes to control over children, whether within the family, in the schools, or in the broader society-I want to vindicate something I have come to call feminist fundamentalism, by which I mean an uncompromising commitment to the equality of the sexes as intense and at least as worthy of respect as, for example, a religiously or culturally based commitment to female subordination or fixed sex roles. ${ }^{2}$

What it might mean in practice for feminist fundamentalism to operate as a necessary constraint on state action is, for any legal system, particularly tricky when that state action involves children. Many who are themselves personally and professionally committed to sex equality in law and life are also committed to honoring other values, including religious freedom, cultural diversity, personal and family autonomy, and sharp limitations on government interference in private life

\footnotetext{
${ }^{1}$ Miss. Univ. for Women v. Hogan, 458 U.S. 718, 725 (1982).

${ }^{2}$ In Case, Constitutional Citizenship, supra note ${ }^{*}$, I explain at length that while the term "fundamentalism" is used in various ways in various contexts, as I use the term, the hallmark of fundamentalism is an inability or unwillingness to compromise.
} 
and individual choice. Properly interpreted, however, existing U.S. law already commits us as a nation to sex equality as a priority, as I will demonstrate. I will also work through concrete examples of what this might mean in practice for governmental interactions with a wide variety of families with children, ranging from civilly united lesbian couples in Vermont to the members of the Fundamentalist Church of Jesus Christ of Latter Day Saints (FLDS) in Texas.

\section{SeX EQuality Is a Particular as Well as a Universal Value}

I could build my vindication of feminist fundamentalism on international human rights norms, because many feminist fundamentalist commitments are not only in accord with, but also independently mandated by, these norms, while some cultural or religious commitments to women's subordination or to fixed sex roles conflict with these norms. Instead, for several reasons, I shall make my case on the basis of U.S. constitutional law.

Nation-states like the United States, as well as individuals such as myself, can have feminist fundamentalist commitments. Focusing on these commitments helps dissolve any perceived dichotomy between feminist or liberal universalism on the one hand and local cultural commitments on the other by highlighting the fact that we, the people of the United States, as well as those elsewhere in the liberal, feminist, constitutional West, have our localized cultural commitments, too, which are at least as important to us, and as entitled to protection and respect, as the local cultural commitments of others are to them. In seeking to dissolve the dichotomy between liberal universalism and cultural particularity, I only wish to bracket, not to deny, disparage, or obviate, universal human rights claims. The fact that some of our local norms are required by and others are at least consistent with universal human rights norms is an independent justification for demanding respect for our norms, quite apart from their cultural significance to us; just as the fact that some other cultural norms violate or are in tension with universal human rights norms is a basis for denying such norms respect notwithstanding their cultural significance. My claim is simply that in addition to whatever force our norms derive from their consistency with universal rights norms, they can also derive additional independent force from the fact of their imbeddedness in and centrality to our particular culture.

Equality and freedom with respect to sex and gender are high among the national cultural commitments of the United States and of the other Western constitutional democracies I have studied as a comparativist. They are also, for some, religious commitments as well. The cultures produced by commitment to sex equality and liberty are at least as extraordinary, fragile, and in need of defense as cultures more generally recognized as unique and endangered, such as those of, say, the hunter-gatherers of Papua New Guinea. Very few cultures over the history or territorial expanse of the world have embraced commitments to sex equality, to the repudiation of fixed sex roles, or to the integration of the sexes, and they 
remain at risk. ${ }^{3}$ I happen to be contingently lucky that my own personal feminist fundamentalist commitments are pretty close to those embraced by the constitutional culture in which I live, although I am just old enough to have developed them as my personal commitments before the U.S. Supreme Court enshrined them in constitutional jurisprudence. ${ }^{4}$

There are two main ways of formulating the principle behind a norm against the denial of equal protection on grounds of sex. The first is that women should not be subordinated, by the law or, more broadly, by men. The second is that sex should be irrelevant to an individual's treatment by the law, and,-more broadly, to his or her life chances. On this latter view, "fixed notions concerning the roles and abilities of males and females" are anathema when embodied in law, even in law that does not in any articulable way subordinate women to men. ${ }^{5}$ And it is this latter view, which repudiates fixed sex roles as well as female subordination, which has become our national constitutional orthodoxy, enshrined in an unbroken line of U.S. Supreme Court case law since the 1970s. ${ }^{6}$

My use of religiously inflected terms such as orthodoxy and anathema in this context is deliberately intended to press several analogies to the discourses of religion. First, just as, for example, the new constitution of Iraq provides that "[n]o law that contradicts the established provisions of Islam may be established,"? so in the United States, no law that contradicts the equality of the sexes may be established. Together with racial equality and the nonestablishment of religion, the equality of the sexes is among the very few commitments the existing U.S. constitutional order makes fundamentally binding on government whenever it acts or speaks. Secondly, just as a shared commitment to the principles of Christianity or to Islam can work itself out in importantly different ways among different denominations or communities of believers, so a commitment to sex equality, like commitments to, for example, freedom of speech or religious liberty, although widely shared among liberal constitutional nation-states, can be spelled out in importantly different ways by different constitutional cultures.

My case for feminist fundamentalism could be made with respect to any number of other constitutional orders, including the Canadian and European legal systems I have studied as a comparativist, but it would need to be made in a

${ }^{3} I d$.

${ }^{4}$ I explain further the origins of my commitments in Mary Anne Case, No Male or Female, in TRANSCENDING THE Boundaries of LAW: GENERATIONS OF FEMINISM AND LEGAL THEORY (Martha Albertson Fineman ed., forthcoming Dec. 2009).

${ }^{5}$ Miss. Univ. for Women v. Hogan, 458 U.S. 718, 725 (1982).

${ }^{6}$ See Mary Anne Case, "The Very Stereotype the Law Condemns": Constitutional Sex Discrimination Law as a Quest for Perfect Proxies, 85 CoRnell L. REV. 1447, 147374 (2000).

[Constitution] § I, art. 2, First, A. (Iraq). 
culturally as well as legally specific way. ${ }^{8}$ Thus, for example, a feminist fundamentalist perspective on the French legal system would have to take account of both parité and mixité, as well as the interaction of these specifically French feminist commitments with other fundamental French values. As French President Nicolas Sarkozy said, 'The meaning, the values, of French 'identity' is clear. It means laicity, sexual equality, opportunity. I believe in a mix, not in communitarianism, and, when you forget those national values, communitarianism is what you get." That the French mix is somewhat different from the American, or, for that matter, the Dutch, the British, the Canadian, or the German, leads France, famously, to answer the question of whether Muslim girls may wear hijab in public school classrooms differently than these other nations have, although each of these nations, like France, is also committed to the equality of the sexes. ${ }^{10}$

\section{The U.S. SuPREME COURT'S ARTICULATION OF SEX EQUALITY AS A PRIORITY}

Although both religious freedom and family autonomy are protected by the Constitution of the United States, the Supreme Court has also made clear that:

the family itself is not beyond regulation in the public interest .... And neither rights of religion nor rights of parenthood are beyond limitation. Acting to guard the general interest in youth's well being, the state as parens patriae may restrict the parent's control by requiring school attendance, regulating or prohibiting the child's labor and in many other

${ }^{8}$ I set forth at greater length my definition of feminist fundamentalism and its implications for both individuals and nation states in comparative perspective in Case, Constitutional Citizenship, supra note *.

${ }^{9}$ Jane Kramer, Round One: The Battle for France, NEW YorkER, April 23, 2007, at $30,37$.

${ }^{10}$ In France, a ban on the wearing of headscarves by pupils in public schools was driven by the French fundamentalist commitment to laïcité, which, contingently and fortuitously, happened to have been worked out historically in opposition to Catholicism and not originally in opposition to the display of Muslim particularity. A similar longstanding fundamental constitutional commitment to secularism led to a similar ban in Turkey, which was upheld by the European Court of Human Rights (ECHR) as being within Turkey's margin of appreciation. But the petitioner in the Turkish case, Leyla Sahin, completed her education, still veiled, in a university in Austria, which has no comparable commitment to secularism. More recently, the British House of Lords, invoking, not secularism, but the British value of reasonable compromise, sided with the governors of a state school, who were prepared to allow their pupils, the overwhelming majority of whom were Muslim, to wear a uniform veil, but not the more all-encompassing jilbab. For further discussion, see Mary Anne Case, Feminist Fundamentalism and Constitutional Citizenship, supra note *. 
ways. Its authority is not nullified merely because the parent grounds his claim to control the child's course of conduct on religion or conscience.

... Parents may be free to become martyrs themselves. But it does not follow they are free, in identical circumstances, to make martyrs of their children before they have reached the age of full and legal discretion when they can make that choice for themselves."

When the state does exert its regulatory power over children and the family, it must do so consistently with its fundamental commitments, including those to equality on grounds of sex as well as race. Among regulations of the family in the public interest are, for example, laws mandating that parents support their minor children. ${ }^{12}$ In the Stanton case, in 1975, the U.S. Supreme Court held that it would be unconstitutional for Utah to require a divorced father to support his son until age twenty-one, but his daughter only until age eighteen. The Court explained:

A child, male or female, is still a child. No longer is the female destined solely for the home and the rearing of the family, and only the male for the marketplace and the world of ideas. . . If a specified age of minority is required for the boy in order to assure him parental support while he attains his education and training, so, too, is it for the girl. To distinguish between the two on educational grounds is to be self-serving: if the female is not to be supported so long as the male, she hardly can be expected to attend school as long as he does, and bringing her education to an end earlier coincides with the role-typing society has long imposed. ${ }^{13}$

In the nineteenth and early twentieth century, Justices of the Supreme Court had been willing to go along with society's sex-role stereotyping. Concurring in a judgment that the state of Illinois could deny a license to practice law to Myra Bradwell, a married woman, Justice Bradley wrote in 1873:

The natural and proper timidity and delicacy which belongs to the female sex evidently unfits it for many of the occupations of civil life. The constitution of the family organization, which is founded in the divine ordinance, as well as in the nature of things, indicates the domestic sphere as that which properly belongs to the domain and functions of

11 Prince v. Massachusetts, 321 U.S. 158, 169-70 (1944) (citations omitted) (upholding the application of laws prohibiting child labor against a woman who had taken her nine year old niece and ward onto the streets of Brockton, Massachusetts to preach and distribute religious pamphlets).

${ }^{12}$ See id. at 165.

${ }^{13}$ Stanton v. Stanton, 421 U.S. 7, 14-15 (1975) (citations omitted). 
womanhood. The harmony, not to say identity, of interests and views which belong, or should belong, to the family institution is repugnant to the idea of a woman adopting a distinct and independent career from that of her husband. ...

... The paramount destiny and mission of woman are to fulfill the noble and benign offices of wife and mother. This is the law of the Creator. And the rules of civil society must be adapted to the general constitution of things, and cannot be based upon exceptional cases. ${ }^{14}$

Since the 1970s, however, as the Stanton case indicates, the United States Supreme Court, interpreting the Equal Protection Clause of the Constitution, has consistently held views such as those expressed by Justice Bradley in the Bradwell case to be not only outdated as a descriptive matter, but impermissible as a normative matter as a basis for governmental decision making. ${ }^{15}$ More generally, the Supreme Court has held all sex stereotypes to be anathema when embodied in law or in other government action.

In one of his last important opinions, Nevada Department of Human Resources v. Hibbs, Chief Justice Rehnquist reaffirmed that we in the United States have so strong and well-established a constitutional orthodoxy on matters of sex and gender-an orthodoxy not simply of sex equality but of no governmentally endorsed sex-role differentiation in all matters including those related to family and child-rearing - that Congress has prophylactic power under Amendment XIV, Section Five to enforce it on the states. ${ }^{16}$ Accordingly, to fight the long-standing, now heretical, "pervasive sex-role stereotype that caring for family members is women's work," 17 Congress can impose on the states as employers the Family and Medical Leave Act (FMLA), which mandates that persons of both sexes, not just women, can get leave from their employers for what Martha Fineman calls their inevitable or derivative dependency, that is to say for their own illness or that of close family members, as well as to care for their young children. ${ }^{18}$

The Hibbs. opinion completes the circle opened in Stanton. When Justice Blackmun's Stanton majority opinion declared: "No longer is the female destined solely for the home and the rearing of the family, and only the male for the marketplace and the world of ideas," there was a subtle lack of parallelism in the formulation ("only the male," not "the male only"). ${ }^{19}$ Women, the Stanton court held, were welcome in both the public and private spheres, but what of men? "Women's activities and responsibilities are increasing and expanding," Blackmun

${ }^{14}$ Bradwell v. State, 83 U.S. (16 Wall.) 130, 141-42 (1873).

${ }^{15}$ Stanton, 421 U.S. at $14-15$.

${ }^{16} \mathrm{Nev}$. Dep't of Human Res. v. Hibbs, 538 U.S. 721, 728-30 (2003).

${ }^{17}$ Id. at 731 .

${ }^{18}$ Martha A. Fineman, The Neutered Mother, the SeXual Family and Other TwentieTH Century TRagedies 161-64 (1995).

${ }^{19}$ Stanton, 421 U.S. at 14-15. 
continued ${ }^{20}$ Indeed they were, but were men's to the same extent? In his majority opinion upholding the FMLA, Rehnquist perfects the parallelism, holding, in effect, that it is no longer solely "the female [who is] destined ... for the home and the rearing of the family.",21

According to Rehnquist, Congress has prophylactic power to target through the FMLA "the faultline between work and family-precisely where sex-based overgeneralization has been and remains strongest"22:

Stereotypes about women's domestic roles are reinforced by parallel stereotypes presuming a lack of domestic responsibilities för men. Because employers continued to regard the family as the woman's domain, they often denied men similar accommodations or discouraged them from taking leave. These mutually reinforcing stereotypes created a self-fulfilling cycle of discrimination that forced women to continue to assume the role of primary family caregiver $\ldots{ }^{23}$

It is in several respects particularly noteworthy that Rehnquist was the author of the Hibbs opinion. Rehnquist was notoriously a latecomer to acceptance of the current constitutional law of sex discrimination's repudiation of distinctions between the roles of men and women. While in the Office of Legal Counsel, he unsuccessfully urged the Nixon Administration to oppose the Equal Rights Amendment, accusing ERA supporters of "a virtually fanatical desire to obscure not only legal differentiation between men and women, but insofar as possible, physical distinctions between the sexes" as well as of "overtones of dislike and distaste for the traditional difference between men and women in the family unit, and in some cases very probably a complete rejection of the woman's traditionally different role in this regard." ${ }^{24}$ As an Associate Justice, he regularly dissented from decisions striking down rules that distinguished on their face between males and females, although he did concur in Weinberger $v$. Wiesenfeld, ${ }^{25}$ which, like Hibbs, concerned sex distinctions in the benefits offered parents of young children. ${ }^{26}$ In that case, plaintiff Stephen Wiesenfeld, who was left with the sole responsibility for the care of his infant son Jason Paul when his wife Paula, the principal wage earner for her family, died in childbirth ${ }^{27}$ challenged a law offering Social Security survivor's benefits only to widows, and not to widowers with young children. ${ }^{28}$

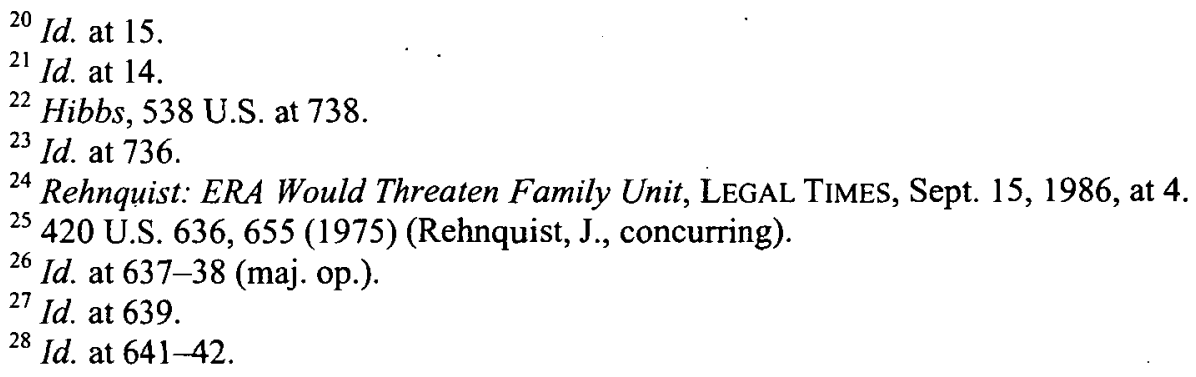


Because Rehnquist saw as the sole legislative purpose for survivor's benefits to "make it possible for children of deceased contributing workers to have the personal care and attention of a surviving parent, should that parent desire to remain in the home with the child," he found it "irrational to distinguish between mothers and fathers when the sole question is whether a child of a deceased contributing worker should have the opportunity to receive the full-time attention of the only parent remaining to it."29

Even so, Rehnquist was not yet fully convinced that a man would find his place in the home. The Wiesenfeld case was one of many sex equality cases argued by Ruth Bader Ginsburg, and the only one in which Rehnquist did not vote against the position for which Ginsburg had advocated. Years later, when Ginsburg had joined him on the Supreme Court, Rehnquist asked her, "Tell me this: did he really take care of the baby?"30 Ginsburg, who had officiated at the wedding of Jason Paul Wiesenfeld, himself now a lawyer, could assure Rehnquist that Stephen Wiesenfeld had indeed taken care of his son. ${ }^{31}$ Rehnquist himself took on child care responsibilities late in life, leaving work early to pick up his granddaughters from school when his daughter, a single working mother, had child care problems. ${ }^{32}$ Perhaps this is what caused him to demonstrate what he himself wryly called "a capacity for growth" when it came to questions of sex discrimination. ${ }^{33}$ Perhaps it was simply his respect for settled law, as articulated in his concurrence in United States v. Virginia, in which he castigated the Virginia Military Institute for failing to take any action in advance of litigation to comply with the constitutional requirement of sex equality. ${ }^{34}$ In any event, although Rehnquist ordinarily gave great constitutional weight to federalism and states' rights, and was as a result reluctant to extend Congressional powers under Section Five, he saw the need for such power to combat "stereotype-based beliefs about the allocation of family duties." ${ }^{35}$ This is further evidence of the fundamental place that not only sex equality, but its instantiation in the repudiation of sex stereotypes has in the United States constitutional order.

The strength of our constitutional commitment to racial equality has led to constitutionally mandated limitations on government tolerance of and participation in private discriminatory acts, including those affecting the custody and education of children. Just as the Stanton case established that state actors cannot take

${ }^{29}$ Id. at 655 (Rehnquist, J., concurring).

${ }^{30}$ Philippa Strum, Women IN THE Barracks: The VMI CASE AND EQual Rights 70 (2002).

${ }^{31}$ Id. at 343 n.16.

${ }^{32}$ Linda Greenhouse, Ideas and Trends: Evolving Opinions; Heartfelt Words from the Rehnquist Court, N.Y. TIMES, July 6, 2003, § 4, at 3.

${ }^{33} \mathrm{Id}$.

${ }^{34} 518$ U.S. 515, 561 (1995) (Rehnquist, J., concurring).

${ }^{35}$ Nev. Dep't of Human Res. v. Hibbs, 538 U.S. 721, 730 (2003). 
societal sex role stereotypes into account in setting child support obligations, ${ }^{36}$ so the 1984 Supreme Court case of Palmore v. Sidoti prohibited any racial discrimination in custody decisions, even when the best interests of an individual child might call for it. ${ }^{37}$ The child in question was the young daughter of divorced white parents in Florida whose father sought to gain custody when her mother married a black man. ${ }^{38}$ The Supreme Court acknowledged, "There is a risk that a child living with a stepparent of a different race may be subject to a variety of pressures and stresses not present if the child were living with parents of the same racial or ethnic origin." ${ }^{39}$ It nevertheless held that the courts were precluded from taking racial prejudice into account in determining custody: "The Constitution cannot control such prejudices but neither can it tolerate them. Private biases may be outside the reach of the law, but the law cannot, directly or indirectly, give them effect." ${ }^{, 40}$ With respect to education, after mandating that public schools no longer segregate pupils on the basis of race, the Supreme Court, by restricting local governmental attempts to close public schools and channel subsidies to private racially discriminatory schools, placed limitations on government's ability to assist private actors in finding an end run around school desegregation. ${ }^{41}$

Just as it does with racial equality, government as decision maker must also act consistently with its commitment to sex equality. ${ }^{42}$

Thus, while government as speaker[, actor,] and dispenser of subsidies is free to take a variety of positions, among the positions it may now no longer take nor promote is ... that of Justice Bradley in Bradwell $[v$. State] [to the effect] that, "the natural and proper timidity and delicacy which belongs to the female sex evidently unfits it for many of the occupations of civil life, ${ }^{, 43}$

\footnotetext{
${ }^{36}$ Stanton v. Stanton, 421 U.S. 7,17 (1975).

${ }^{37} 466$ U.S. $429,433-34$ (1984).

${ }^{38}$ Id. at 430.

${ }^{39}$ Id. at 433.

${ }^{40} \mathrm{Id}$.

${ }^{41}$ Norwood v. Harrison, 413 U.S. 455, 462-65 (1973); Griffin v. County Sch. Bd., 377 U.S. 218, 232 (1964).

${ }^{42}$ I first articulated this claim in a response to Kathleen Sullivan's Jorde Symposium lecture, in which Sullivan endorsed "normative pluralism" through "[c]onstitutional immunity for a private sphere" and sought to reinforce a dichotomy between "judicially enforceable and hortatory norms." Kathleen M. Sullivan, Constitutionalizing Women's Equality, 90 CAL. L. REV. 735, 754-61 (2002). In my response, I argued that Sullivan overstated, "even under existing constitutional law, the permissible or desirable scope for normative pluralism on matters concerning women's equality." Mary Anne Case, Reflections on Constitutionalizing Women's Equality, 90 CAL. L. REV. 765, 785 (2002).

${ }^{43}$ Case, supra note 42, at 785 (quoting Bradwell v. State, 83 U.S. (16 Wall.) 130, 141 (1873) (Bradley, J., concurring)) (citations omitted).
} 
notwithstanding that such a position may still be fervently held by many people of faith.

What might this mean in practice? Consider a few examples, some more hypothetical than others. At one extreme of the hortatory axis, what constitutional limits might there be on mere government pronouncements of principle unmoored from direct, binding connection to policy? In 1993, the commissioners of Cobb County, Georgia, adopted resolutions proclaiming, inter alia, "that 'the traditional family structure' is in accord with community standards, that 'lifestyles advocated by the gay community' are incompatible with those standards[,] and that Cobb County would not fund 'activities which seek to contravene these existing community standards.' If, by "traditional family structure," the commissioners had explicitly indicated that they meant, not just a heterosexual couple, but a patriarchal one, with wives submissive to husbands and confined to the domestic sphere as Justice Bradley urged, the resolution would violate existing U.S. constitutional equality norms. "Lifestyles advocated by the [feminist] community" can no longer be "incompatible with the" official community standards of any unit of government in the United States. "Welcome to Cobb County, Where a Woman's Place is in the Home" would be a combination of welcome mat and no trespassing sign with, in my view, serious constitutional problems.

My colleague Judge Richard Posner apparently agrees with me that such a message would be problematic, since he goes so far in a recent opinion as to list "a woman's place is in the home" together with "blacks have lower IQs than whites" among the messages whose psychological effects on children could be such as to allow a public school to forbid students inscribing it on T-shirts they wear to class. $^{44}$

\section{FEMINIST FUndamENTALISM In EdUCATIONAL PROGRAMS}

The problems only intensify when government seeks to use its powers to fund or regulate to promote such a problematic message. Attention to such problems is particularly urgent now that the federal government sends, to children as well as adults, messages about appropriate family structure and sexual behavior backed by carrots and sticks. For example, assuming arguendo that "promoting marriage" through subsidies, hortatory, and regulatory means is an appropriate activity for the federal government, it is still constitutionally constrained to promote only egalitarian marriage. ${ }^{45}$

\footnotetext{
${ }^{44}$ Nuxoll v. Indian Prairie Sch. Dist. \#204, 523 F.3d 668, 674 (7th Cir. 2008).

${ }^{45}$ See Case, supra note 42 , at 786.
} 
Court challenges to programs promoting marriage have to date focused unsuccessfully on claims under the religion clauses, ${ }^{46}$ but the fact that a government-funded program whose promotion of marriages in which wives are to be submissive to their husbands does not rely in a "pervasively sectarian" way on Scripture for its subordinating message should not be enough to shield such a program from further constitutional scrutiny. ${ }^{47}$

As Cornelia Pillard has argued:

If government must not act on the belief that men are aggressive and thus better fit than women for military-style education, women are better mothers, or boys are more likely than girls to drink and drive dangerously, then it should follow that government may not seek to indoctrinate students with those same sex-based generalizations. ${ }^{48}$

Pillard's focus is on the sex stereotypes associated with abstinence-only sex education, including the perpetuation, as both a normative and descriptive matter, of "the stereotyped double standards of virility versus chastity, homemaker versus breadwinner, subject versus object of desire, ${ }^{, 49}$ but her point can be generalized to other aspects of the school curriculum, whether in the public schools themselves or in other government subsidized educational programs. Justice Souter, in dissent from his colleagues' decision upholding a program of government-funded vouchers parents could use to pay for religious schools, wrote that not "every secular taxpayer [will] be content to support Muslim views on differential treatment of the sexes, or, for that matter, to fund the espousal of a wife's obligation of obedience to her husband, presumably taught in any schools adopting the articles of faith of the Southern Baptist Convention." Souter and say that it would already be unconstitutional for the government to fund this sort of teaching, in the same way as it has been held unconstitutional for the government to fund racial segregation. ${ }^{51}$

Parents with religiously based objections to public school curricula presenting an untraditional view of sex roles have long been told by federal courts that they have no right either to force a public school to change its curriculum or to opt their

${ }^{46}$ See, e.g., Christianson v. Nw. Marriage Inst., 482 F. Supp. 2d 1237, 1243-48 (W.D. Wash. 2007) (focusing on the Establishment Clause).

47 See Deborah A. Widiss et al., Exposing Sex Stereotypes in Recent Same-Sex Marriage Jurisprudence, 30 HARV. J.L. \& GENDER 461, 501 (2007).

${ }^{48}$ Cornelia T.L. Pillard, Our Other Reproductive Choices: Equality in Sex Education, Contraceptive Access, and Work-Family Policy, 56 EMORY L.J. 941, 956-57 (2007) (citations omitted)

${ }^{49} \mathrm{Id}$. at 953 .

50 Zelman v. Simmons-Harris, 536 U.S. 639, 716 (2002) (Souter, J., dissenting) (citations omitted).

${ }^{51}$ Norwood v. Harrison, 413 U.S. 455, 464-65 (1973). 
children out of those portions of the curriculum containing messages of sex equality. Thus, in one leading case, born-again Christian Bob Mozert was unsuccessful in his court challenge to his children's being exposed by their public school curriculum to "role reversal or role elimination, particularly biographical material about women who have been recognized for achievements outside their homes." ${ }^{.52}$ Apostolic Lutheran parents in another school district, upset that "schools are contributing to the Womans' [sic] Liberation Movement by making [it] mandatory that the boys take home economics and the girls take shop," similarly failed to persuade a court that they were constitutionally entitled to have their children excused from portions of the curriculum the parents found objectionable on religious grounds. ${ }^{53}$ But, in rejecting the parents' free exercise claims, the courts in neither of these cases explicitly relied on constitutional sex-equality guarantees. $^{54}$

In my view, the courts could have gone much farther, treating the schools' choice of materials that challenged sex stereotypes, not as merely permissible and as such immune from a free-exercise challenge, but as constitutionally required to provide to both male and female students equal protection on grounds of sex. State-sponsored education is not merely permitted, but also required to refrain from promoting a message of inequality between men and women. Although the constitutional argument is more complicated, the limitation should be no different when it shifts from the public school to those forms of private or home schooling that are authorized by the state as substitutes for public education. Unfortunately, when one moves beyond those institutions bound by Title IX, there has to date been comparatively little in the way of regulatory attention paid in the United States to ensuring that the education provided to students through state-regulated private and home schooling even minimally communicates or comports with norms of sex equality. But scholars such as James Dwyer and Kimberly Yuracko are right to insist that the state is under a constitutional obligation to protect children from receiving a discriminatorily inferior education on grounds of sex, whether or not that education is in a private or home school and whether or not it is dictated by the parents' religious beliefs. ${ }^{55}$

Some might suggest that the U.S. Supreme Court case of Wisconsin v. Yoder, in which the Old Order Amish were allowed as part of their constitutionally protected free exercise of religion to withdraw their teenage children from school in contravention of school attendance requirements, stands in the way of the argument here. ${ }^{56}$ But subsequent decisions have made quite clear that the Yoder

\footnotetext{
${ }^{52}$ Mozert v. Hawkins County Bd. of Educ., 827 F.2d 1058, 1062 (6th Cir. 1987).

${ }^{53}$ Davis v. Page, 385 F. Supp. 395, 403-06 (D.N.H. 1974).

${ }^{54}$ Mozert, 827 F.2d at 1063-65; Davis, 385 F. Supp. at 405-06.

s5 See JAMES G. DWYER, RELIGIOUS SCHOOLS V. CHILDREN's RIGHTS 85-86 (1998); Kimberly A. Yuracko, Education off the Grid: Constitutional Constraints on Homeschooling, 96 CAL. L. REV. 123, 156 (2008).

${ }^{56} 406$ U.S. 205, 235-36 (1972).
} 
case will be essentially limited in its application to the Amish. ${ }^{57}$ Moreover, although the Amish resisted higher education for their children, they apparently did not distinguish between boys and girls in so doing, giving both sexes similar training. ${ }^{58}$ Scholars who studied them at about the time of the Yoder decision reported:

Although the Amish girls always wear dresses and the little boys, after they are toilet-trained, wear trousers, there is little difference in tasks they are taught to perform. Boys are encouraged to like horses and machinery, but children of both sexes accompany their father around the farm and help their mother with simple household tasks. ${ }^{59}$

Had the Amish insisted on pulling only their daughters out of school without a high school diploma, while also insisting on sending their sons to college, the case would be more on point here.

\section{SeX Equality IN EdUCATIONAL PROGRAMS Is LiNKED to EQUALITY FOR GAYS AND LESBIANS}

The Apostolic Lutheran parents who unsuccessfully litigated in federal court to stop boys from taking home economics were worried about more than Women's Liberation. They also expressed concern that:

boys between [the] ages of 12 and $16 \ldots$ are very vulnerable to effeminate or homosexual development if [a] certain environment is provided. ... [I]f students who already have possible unknown problems in this area were placed in this atmosphere condoned and imposed by those in authority it would certainly contribute to a particular students [sic] overall destruction of masculinity. Men are the head of the family not the homemakers. ${ }^{60}$

Similarly, as part of a successful attempt to persuade Governor Arnold Schwarzenegger to veto the Bias Free. Curriculum Act, which would have prohibited educational materials used in California schools from reflecting adversely on persons because of, inter alia, their gender or sexual orientation, ${ }^{61}$

${ }^{57}$ See, e.g., Blackwelder v. Safnauer, 689 F. Supp. 106, 135 (N.D.N.Y. 1988)(“In sum, the holding in Yoder must be limited to its unique facts and does not control the outcome of plain-tiffs' free exercise challenge in this case.").

${ }^{58}$ Yoder, 406 U.S. at 208-09 n.3.

59 John A. Hostetler \& Gertrude Enders Huntington, Children in AMish SOCIETY: SOCIALIZATION AND COMMUNITY EDUCATION 18 (1971).

${ }^{60}$ Davis v. Page, 385 F. Supp. 395, 403 (D.N.H. 1974).

${ }^{61}$ S.B. 1437, 2005-06 Leg., Reg. Sess. (Cal. 2006). 
Luis Goldamez, Latino spokesman for the Campaign for Children and Families, insisted:

We can no longer allow girlie-men in this state or any state to dictate to our children what they're going to teach them. We need to see them face-to-face and tell them, we have our pants on the right way, we are men and women, we are not confused. And if anyone needs to teach our children, it needs to be us parents, not girlie-men from this building or any other building. ${ }^{62}$

One of the myriad ways that the equality of the sexes is linked to gay rights is that those with a religiously based insistence on promulgating fixed sex roles or female subordination often explicitly link it to a religiously based opposition to tolerance for or recognition of homosexual behavior and relationships. It behooves both feminist fundamentalists and advocates for gay and lesbian rights to be more attentive to and explicit about these connections.

Consider, for example, U.S. Secretary of Education Margaret Spellings's decision to force out of the Public Broadcasting Service (PBS) television series Postcards from Buster an episode featuring a lesbian civilly united couple from Vermont who run a maple sugaring operation with their three children. ${ }^{63}$ The episode featuring the Vermonters was called "Sugartime," and there were snide suggestions in the reporting on Spellings's actions that "sugaring" was thought to refer to an exotic sexual practice, although in fact, of course, the reference was simply to the routine production of maple sugar. ${ }^{64}$ Although Postcards from Buster had received federal funding specifically to showcase the diversity of American families, and although the series had included, without objection from Spellings, a Muslim family who veiled their preteen daughter, as well as evangelical Christian and Mormon families, Spellings claimed, in a letter to PBS officials, that "[m]any parents would not want their young children exposed to the life-styles portrayed in this [Sugartime] episode." ${ }^{.65}$ No apparent account was taken of those "many parents" who might not want their children exposed to the religiously traditional "life-styles" portrayed in other episodes. Not only is Spellings's decision constitutionally problematic viewpoint discrimination, feminists and proponents of equality for gays and lesbians have common cause to object to it.

${ }^{62}$ Brave New Schools: 'Sexual Indoctrination' Bill Vetoed, WorLdNETDAILY, Sept. 6, 2006, http://www.worldnetdaily.com/news/article.asp?ARTICLE_ID=51866.

${ }^{63}$ Letter from Margaret Spellings, U.S. Secretary of Education, to Pat Mitchell, President and CEO, Public Broadcasting Service (Jan. 25, 2005), available at http://www.ed.gov/ policy/elsec/guid/secletter/050125.html [hereinafter Letter from Margaret Spellings].

${ }_{64}$ Julie Salamon, A Child Learns a Harsh Lesson in Politics, N.Y. TIMES, Feb. 5, 2005, at B7.

${ }^{65}$ Letter from Margaret Spellings, supra note 63. 


\section{FEMINIST FUNDAMENTALISM IN CHILD CUSTODY AND ADOPTION ${ }^{66}$}

As has been clear for some time when it comes to state laws governing matters such as alimony and child support, "[s]ex equality norms also [should] constrain government on those occasions when [the state] necessarily adjudicates concerning the family." ${ }^{, 67}$ In the remainder of this Article, I will work through examples, some more controversial than others, of what this might mean for parents and children. Among the questions I will consider is to what extent government in its adjudication of custody as between already-recognized parents or its placement of children for adoption should take commitment or opposition to women's equality into account. Before readers protest that I am proposing massive government intervention into constitutionally protected parenting choices, it is important for me to stress that I am focusing my attention here on situations where there is already, of necessity, governmental intervention. In such situations, a policy of noninterference in the family or of leaving things up to autonomous individuals to decide for themselves simply is not an option. A custody dispute between two divorcing parents, for example, must be resolved-if neither parent is unfit, a court must decide between them in the best interests of the child.

In deciding such cases, evidence of commitment to sex equality should be as at least as assiduously enquired into and at least as positively weighted as a prospective adoptive or custodial parent's commitment to providing a child with religious training, something many decision makers in adoption and custody cases seem to enquire into and weigh favorably, often without much apparent attention to the substance of the religious beliefs. It is notoriously difficult to determine what is actually happening as a general matter in family law cases, given how few result in reported decisions and how manipulable and vulnerable to judicial bias, conscious or unconscious, the relevant standards, such as "best interests of the child," are. From the few reported cases it appears, however, that when repressive religious beliefs are pitted against secular feminist ones, the religious beliefs often begin with a presumption to respect I want to insist is even more deserved, but I realize is often not granted, to the feminist ones.

Consider, as a frightening example, the case of Laurie April Wang, who left her husband after his church subjected her to an exorcism, as it had another woman, to "to rid herself of the 'evil unsubmissive spirits'-the spirits which caused her to speak up for herself and to exercise authority rather than completely submit to her husband." ${ }^{\circ 8}$ A court adjudicating her custody dispute was unwilling to consider whether her husband's religious convictions and his efforts to pass them on to his son might adversely affect her relationship with her son, apparently

${ }^{66}$ The argument in this section is at the core of Case, Baby Markets, supra note *.

${ }^{67}$ Case, supra note 42 , at 786.

${ }^{68}$ In re Marriage of Wang, 896 P.2d 450, 454 (Mont. 1995) (Leaphart, J., dissenting) (quoting testimony from the record). 
because it "took the position that religion is beyond the pale of the court's scrutiny." 69

Even courts that do, in the end, rule against parents who claim religious authority for the sexist beliefs and practices those parents seek to impose on their children often do so without giving any explicit consideration to the role constitutional norms of sex equality should play in their decision making. Thus, in Roberts $v$. Roberts, a Virginia judge did terminate a father's visitation with his son and daughter after hearing testimony by a clinical psychologist that the daughter "is particularly at risk of psychological damage because of [her father's] telling her that women should not strive to accomplish what men accomplish and that they are supposed to be subservient to men"; ${ }^{70}$ evidence that the daughter, an "excellent student," occurred, than she did last academic year, when there was visitation"; $;{ }^{72}$ and evidence that the father had told both children that they and their mother, whom he called "a sinner" 73 and "“of the devil,", 74 would all go to hell. ${ }^{75}$ The judge concluded that visitation with the father was "causing serious psychological and emotional damage to the children" in no small part because "the values being taught to the children by [their father] are different from the values being taught to the children by [their mother]. ${ }^{, 76}$ Among these conflicting sets of values were that the mother "encourages the children to be whatever they want to be. [The father] tells [his daughter] women cannot do what men do., ${ }^{, 77}$ But, even with respect to these values, the court insisted only, "Whichever set of values is right, and the court makes no judgment on which set of values is right, they are irreconcilably at odds." 78

It may well be true that, as between "tolerance" and "fire and brimstone",79 another of the enumerated conflicts in values between these particular parents-a court can make no judgment, but I would argue that a court is constitutionally compelled to choose encouragement of a daughter's choice of occupation over a fixed and subordinating message that "women cannot do what men do." ${ }^{\text {"To }}$ That is not to say that the parent who most favors sex equality should always prevail, simply that a court must not remain viewpoint neutral as between sex equality and

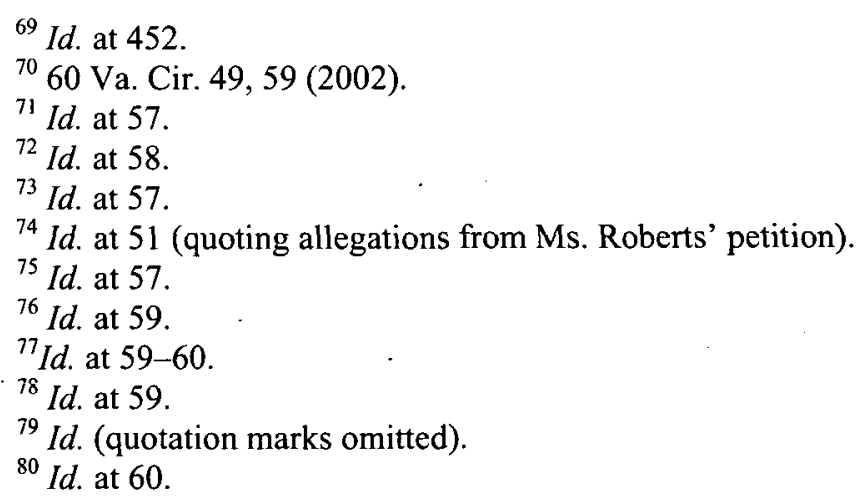


its opposite; it must put a thumb on the scales in favor of the parent who would give a daughter the same encouragement, liberty, and opportunity as a son.

If the son or daughter makes use of this liberty to develop interests and ambitions traditionally and stereotypically not associated with his or her sex--if he develops an interest in nursing or she in engineering - this should not be seen as a harm, but as a vindication of our commitment as a constitutional culture not to enshrine "fixed notions concerning the roles and abilities of males and females." Sociologist Judith Stacey has reported data suggesting that among the few differences between children raised in lesbian households and other children is that those raised in lesbian households, particularly girls, are somewhat more likely to "behave in ways that do not conform to sex-typed cultural norms," have a "greater interest in activities associated with both 'masculine' and 'feminine' qualities and that involve the participation of both sexes," and have a greater interest in pursuing careers in fields traditionally dominated by the opposite sex. ${ }^{82}$ If these reported differences are to play any role at all in governmental decision making about lesbian parenting, they should cut in favor of, not, as some opponents of gay rights have argued, against, recognition of lesbian parents. ${ }^{83}$

Although my take on cases like Wang and Roberts is consistent with the analysis of scholars such as James Dwyer, who has written extensively about religious exemptions to child welfare and education laws as denials of equal protection to children of religious objectors, ${ }^{84}$ it is directly at odds with that of some scholars of the First Amendment. ${ }^{85}$ Most notably, Eugene Volokh has argued that the First Amendment requires that views such as those articulated by Messrs. Wang and Roberts not be stifled. ${ }^{86}$ The hierarchy of U.S. constitutional values is not as Volokh suggests, however. It is not the free exercise or free speech clause that is on a par with equal protection on grounds of race and sex when it comes to the extent of the limitations it places on government action; it is the establishment clause, and, in cases such as Wang and Roberts, the prohibition on government's establishing a religion and the guarantee of equal protection on grounds of sex cut in the same direction-against the parent insisting on a religiously grounded commitment to female subordination.

${ }^{81}$ Miss. Univ. for Women v. Hogan, 458 U.S. 718, 724-25 (1982).

82 Judith Stacey \& Timothy J. Biblarz, (How) Does the Sexual Orientation of Parents Matter?, 66 AMER. SOC. REV. 159, 168 (2001).

${ }^{83}$ Case, Baby Markets, supra note *.

${ }^{84}$ See DWYER, supra note 55, at 121-47 (arguing that parental religious exemptions are unconstitutional).

${ }^{85}$ See, e.g. Eugene Volokh, Parent Child Speech and Child Custody Speech Restrictions, 81 N.Y.U. L. REV. 631, 673-712 (arguing that most child custody speech restrictions are unconstitutional).

${ }^{86}$ See id. at 686 (arguing that "[c]hild custody speech restrictions also can't be justified simply by arguing that protecting a child's best interests is so important that it trumps any First Amendment rights"). 
One of the reasons the First Amendment may be seen to complicate the analysis in cases like Wang and Roberts is that both involved conflicts over gender ideology reflected largely in the fathers' discriminatory speech, rather than in any other alleged discriminatory treatment of children on grounds of sex. Harmful though it may be for Mr. Roberts to tell his daughter that her options are more limited than her brother's, it might have been even easier for a court to see the harm had her father also pulled her out of school in accordance with his ideology.

Because religious liberty claims played such a central role in decisions such as Yoder ${ }^{87}$ there is every reason to believe as a matter of law that a parent who limits a daughter's education or loads her down with chores will get less respect from a court for this decision if it is only culturally, and not also religiously grounded. Indeed, courts, many dealing with immigrant families in which not only gender role ideology, but a parent's genuine pressing need for help around the house may keep a girl out of school, generally seem to have fewer problems favoring the parent who equalizes educational opportunity when religion is not at issue. ${ }^{88}$ This may cause consternation among some scholars, but I think it was, for example, perfectly appropriate for a Nevada court that awarded custody of a young Mexican girl to her U.S.-resident father in preference to her illegal immigrant mother to take into account, among other things, that while in her mother's custody the girl had been forced to assume substantial care-giving responsibilities for her disabled brother. ${ }^{89}$

Similarly, I think it appropriate that a court considering a teacher's petition to remove eleven-year-old Linda Berrero Cano from the custody of her migrant Mexican mother and to adopt her considered, among other things, how many school days the girl had unwillingly missed in order to care for her siblings. ${ }^{90}$ Linda's case was drawn to my attention by.Michele Goodwin, who is critical of a judicial system that removes a child from her mother's poor, unassimilated, Spanish-speaking home to place her with a family that "lives in a brick ranch house with a basketball hoop in the driveway, a swimming pool in the backyard."91 But Goodwin lists as the factors that determine the loser in competition for Linda only "[p]overty, immigrant status, limited political clout, and limited English proficiency," nothing connected to sex and gender roles. ${ }^{92}$ I agree with her that

${ }^{87} 406$ U.S. 205 (1972).

${ }^{88}$ See, e.g., Rico v. Rodriguez, 120 P.3d 812, 816 (Nev. 2005) (affirming award of custody to the parent who, among other things, could provide "stable schooling for the children").

${ }^{89}$ Rico, 120 P.3d at 815.

${ }^{90}$ See Shaila Dewan, Two Families, Two Cultures and the Girl Between Them, N.Y. TIMES, May 12, 2005, at Al6 (reporting that "Linda says her family hit her and for a time kept her out of school to take care of younger siblings").

${ }^{91}$ Michele Goodwin, The Free-Market Approach to Adoption: The Value of a Baby, 26 B.C. THIRD WORLD L.J. 61, 71 (2006).

${ }^{92} I d$. at 72 . 
there is cause for concern when a judge in a custody dispute overvalues the material and cultural advantages of growing up in a wealthy, assimilated, Englishspeaking household, and I know too little about the facts of the case to be in a position to evaluate its bottom-line result, but, in apparent contrast to Goodwin, I think Linda's being unwillingly kept out of school to perform household labor is an important factor for the judge to take into consideration.

Government should "disfavor in competition for children those who, for example, would make a girl do all the household chores while her brother"93 can study or play. Though the cases that get press attention in this regard tend to feature families that are culturally, ethnically, or religiously exotic, from the polygamous FLDS to Muslim and Mexican immigrants, recently released data on the chores performed by children show that, even in mainstream American families, girls in many households do in fact spend far more hours on household chores than boys, leaving boys more time to play and to study ${ }^{94}$ Moreover, the chores girls are given to do are less likely to be paid and less likely to be marketable than those assigned to boys. ${ }^{95}$ Notwithstanding that, as Viviana Zelizer points out, in the nineteenth century families often took in foster children principally to have an extra pair of hands for farm chores and household tasks, ${ }^{96}$ we would today find unthinkable the adoption of a Black child to be, in effect, a household servant for his or her White adoptive siblings. We should feel similarly about a girl expected to serve her brothers.

I also agree with Goodwin that it is noteworthy that "Linda Berrero Cano was never surrendered by her mother to the state, nor was she in foster care," when her teacher sought to adopt her. ${ }^{97}$ Unlike custody disputes between two alreadyrecognized parents, or adoption decisions when there are multiple prospective adoptive parents, Linda's case did not have two contenders for custody who began on a presumptively equal plane. ${ }^{98}$ For the teacher to prevail over the mother ordinarily would require a finding of parental unfitness, a much higher standard.

The case for feminist fundamentalism being outcome determinative in custody or adoption decisions is, other things being equal, stronger a) when those competing for a child begin with presumptively equal rights in that child, as occurs in a custody fight between two recognized parents or an adoption decision when there are multiple qualified adoptive parents; b) when both ideology and actions

${ }^{93}$ Case, supra note 42 , at 787.

94 See Sue Shellenbarger, Boys Mow Lawns, Girls Do Dishes: Are Parents Perpetuating the Chore Wars?, WALL ST. J., Dec. 7, 2006, at D1 (reporting inter alia that according to a University of Michigan nationwide study "boys spend an average $30 \%$ less time doing chores" than girls).

${ }^{95}$ Id.

96 Viviana A. Zelizer, Pricing the Priceless Child: The Changing Social VALUE OF CHILDREN 170 (1985).

${ }^{97}$ Goodwin, supra note 91 , at 71 .

${ }^{98}$ Id. 
are discriminatory; c) when only culture, not religion, is used to justify the antifeminist contender; d) when the child is a girl, although, as the Wang and Roberts cases show, a son can also be at risk; and most importantly d) when the antifeminist acts or speech rise to the level of child abuse, so as potentially to justify a finding of parental unfitness.

Even those who may find the examples I have thus far cited in this Article unpersuasive would surely agree that there is some point on the continuum at which a parent's speech or action in support of a commitment to female subordination or rigid sex roles would cross the line into abuse. For example, those who might not agree that it should count against a parent that he tells his daughter her place is in the home doing housework might feel differently if he kept her chained there day and night, an illiterate drudge, and might then favor state intervention, even if there was no recognized competitor for his daughter's custody, and even if he gave religious justifications for so severely restricting her.

\section{CONCLUSION: THE TEXAS FLDS CASE AS AN EXAMPLE OF HOW NOT TO APPLY THE DISCOURSES OF RELIGION AND HUMAN RIGHTS TO CHILDREN}

Unfortunately, the fact that sex-role differentiation with roots in female subordination seems so "familiar" inhibits support for state intervention to combat it. ${ }^{99}$ Consider, for example, the reaction to the state of Texas's April 2008 attempt to remove more than 400 children from parents who were members of the Fundamentalist Church of Jesus Christ of Latter Day Saints living on the Yearning for Zion Ranch. ${ }^{100}$ The state's intervention was prompted by reports that a sixteenyear-old girl was being forced to marry a forty-nine-year-old man. ${ }^{101}$ The state did find that "more than 30 of the 53 girls from 14 to 17 who were at the ranch are pregnant or have children." 102 A quick overview of public commentary on the state's action reveals that few, other than representatives of the State of Texas itself and self-identified survivors of polygamy, have been quoted in support of the state's action, however. Pundits on both the left and right condemned the state's intervention into the family and the community. ${ }^{103} \mathrm{I}$ agree that the strict

${ }^{99}$ Cf. Lynch v. Donnelly, 465 U.S. 668, 696-97 (1984) (Brennan, J., dissenting) (noting, in an Establishment Clause case, that, "because the Christmas holiday seems so familiar and agreeable" the Court's majority is blinded to the "distinctively sectarian" nature of the display of a crèche in the public square).

${ }^{100}$ See Dan Frosch, Texas Reports Further Signs of Abuse at Sect's Ranch, N.Y. TIMES, May 1, 2008, at A16.

${ }^{102} \mathrm{Id}$.

103 See, e.g., ACLU Statement on YFZ Ranch (May 2, 2008), http://www.aclutx.org/article.php?aid=570 (expressing concern that "[p]arents have been separated from their children without individual, adversarial hearings and without particularized evidence that they ever engaged in abuse or were likely to engage in abuse"). 
preconditions Texas law sets before children can be removed from their homes on an emergency basis were not satisfied in this case, and that the Texas courts therefore had little choice but to order the children's prompt return. ${ }^{104}$

But I am disturbed by the dismissive way in which the Texas Court of Appeals, whose decision that the children should be returned was upheld by the Texas Supreme Court, treated the Texas Department of Family and Protective Services's allegations of danger to the children. The Department took the position that "due to the 'pervasive belief system' of the FLDS, the male children are groomed to be perpetrators of sexual abuse and the girls are raised to be victims of sexual abuse." 105 But the Texas Court of Appeals repeatedly insisted that the Department had made no showing of "any risk to them other than that they live in a community where there is a 'pervasive belief system' that condones marriage and child-rearing as soon as females reach puberty," as if this in itself were no big deal. ${ }^{106}$ To help clarify why I find the court's attitude so disturbing, imagine that instead of the "pervasive belief system" of the FLDS concerning adolescent female sexual activity with older males, the court had instead been faced with the pervasive belief system of the Sambia of New Guinea, who, as documented by anthropologist Gilbert Herdt, held and acted on the view that if young boys did not regularly fellate older males and ingest their semen, thereby replacing mother's milk with male milk, they would never grow up to be proper men themselves. ${ }^{107}$ Would the court have sent young boys back to their families so promptly after finding that they "were in [no] physical danger other than [they] live ... among a group of people who have a "pervasive system of belief' that condones," not "polygamous marriage and underage females having children" as did the FLDS, ${ }^{108}$. but underage males regularly fellating older males as did the Sambia? Surely not. Perhaps this is because the FLDS's "umbrella of belief" that for girls, "having children at a young age is a blessing""109 is more "familiar and agreeable" 110 to the Texas courts than the Sambian "umbrella of belief" that for boys, ingesting semen at a young age is a comparable blessing.

${ }^{104} \mathrm{I}$ am therefore not suggesting that the bottom line decision of the Texas courts that by law the children should be returned forthwith to their FLDS parents was incorrect. There did not seem to be evidence of imminent physical harm to all the children, nor did it seem that Texas had taken heroic measures to find a solution short of immediate removal, as the law requires. See In re Tex. Dep't of Family \& Protective Servs., 255 S.W.3d 613, 615. (Tex. 2008) (stating that "[o]n the record before us, removal of the children was not warranted").

${ }^{105}$ In re Steed, No. 03-08-00235-CV, slip op. at 4 (Tex. App. May 22, 2008).

${ }^{106} \mathrm{Id}$. at 7.

107 Gilbert Herdt, The Sambia: Ritual and Gender in New Guinea xv (2d ed. 2005).

${ }^{108}$ In re Steed, slip op. at 7.

${ }^{109} \mathrm{Id}$. at $6 \mathrm{n} .8$ (quoting the Texas Department of Family and Protective Services' lead investigator).

${ }^{110}$ Lynch v. Donnelly, 465 U.S. 668, 696 (1984) (Brennan, J., dissenting). 
It remains unclear where in the cycle of socialization into an "umbrella of belief" such as that of the FLDS courts are prepared to intervene so as to protect young girls. If the age of consent remains unchanged, impregnating the girls remains a crime. ${ }^{111}$ But, does the after-the-fact possibility of long sentences for statutory rape for men who have sex with young girls trained to believe they risk their salvation if they don't cooperate actually prevent harm to the girls? Shouldn't some efforts be made to intervene earlier, before the girls are pregnant?

Yet even when one parent strongly objects to socialization into underage polygamy, courts seem reluctant to rule in favor of that parent. Consider the Pennsylvania Supreme Court's disposition of the custody dispute between the divorcing Shepps. ${ }^{112}$ Their divorce had been occasioned by his conversion to a fundamentalist polygamous variant of Mormonism from the more traditional Mormonism both parents had previously practiced. ${ }^{113}$ The trial court had heard evidence that he had told his thirteen-year-old stepdaughter that her salvation depended on her practicing polygamy, and that when she turned fourteen she should marry him, her stepfather. ${ }^{114}$ In its final order, the trial court "specifically prohibited" him "while [his biological] child is a minor from teaching her about polygamy, plural marriages or multiple wives,"' and an intermediate appellate court upheld the trial court's order, noting that the record indicated that "'promotion of his beliefs to his stepdaughter involved not merely the superficial exposure of a child to the theoretical notion of criminal conduct, but constituted a vigorous attempt at moral suasion and recruitment by threats of future punishment." $" 115$ But the Supreme Court of Pennsylvania reversed, saying that, even when it came to "religious beliefs, which, if acted upon, would constitute a crime," their promulgation to a child could not be restricted unless it were "established that advocating the prohibited conduct would jeopardize the physical or mental health or safety of the child, or have a potential for significant social burdens." ${ }^{116}$ I agree with the dissenting judge that such a showing had clearly been made in the Shepp case. ${ }^{117}$

As I see it, in both the Shepp and the Steed cases, court majorities were not only far too willing to be deferential to religious justifications, but also, in addition, far too unwilling to treat female subordination through traditional sex roles as something unusual and disturbing. Similarly, the court-appointed social

111 Tex. Penal CODE ANN. $\S 22.11$ ("A person commits an offense if, with a child younger than 17 years and not the person's spouse, whether the child is of the same or opposite sex, the person: (1) engages in sexual contact with the child or causes the child to engage in sexual contact.").

${ }_{112}$ Shepp v. Shepp, 906 A.2d 1165, 1166 (Pa. 2006).

${ }^{113}$ Id. at $1166-67$ \& $\mathrm{n} .2$.

${ }^{114} \mathrm{Id}$. at 1168 .

${ }^{115} \mathrm{Id}$.

${ }^{116} I d$. at 1174 .

${ }^{117}$ Id. at $1176-80$ (Baer, J., dissenting). 
worker in the Wang case found after an investigation that there "were no "bizarre activities going on' at the Cornerstone Community Church but rather it was merely a fundamentalist church," ${ }^{118}$ notwithstanding testimony about the lengths, including exorcism of supposed demons, the church was prepared to go to ensure compliance with its "teach[ing] that women are not allowed any authority, and that men must be allowed to make all the decisions." 119

What may help account for the tendency of both left and right to support the FLDS against the Texas Department of Family and Protective Services is a related, though simultaneously diametrically opposite phenomenon, to that afflicting the court majorities: both sides of the political spectrum tended to focus on those aspects of the FLDS's situation with which they could most readily identify. The religious right could make common cause with the FLDS's religiously based conformity to traditional sex roles and patriarchal authority; the secular left could focus instead on the ways in which the FLDS was nonconforming and culturally distinct. Each by extension could fear the implications for its own divergences from mainstream culture from any successful attempt to force the FLDS to move to the mainstream.

A feminist fundamentalist take on the FLDS case, especially one informed by information available about the Y Yearning for Zion Ranch from sources in addition to those cited by the Texas courts, might instead see the case as an object lesson in what can go wrong when the constitutional mandate of equal protection on grounds of sex is not systematically and with full force applied in state regulation of the family and the education of children. A consistent story emerges from the autobiographies of Elissa Wall, whose court testimony about her forced marriage at age fourteen helped put FLDS leader Warren Jeffs in jail as an accomplice to rape; ${ }^{120}$ of Carolyn Jessop, who successfully challenged the FLDS elder whose fourth wife she became at age eighteen for sole custody of the eight children she ultimately bore him; ${ }^{121}$ and of the four former FLDS women among the eighteen "women who escaped" polygamy whose stories are told in God's Brothel. ${ }^{122} \mathrm{We}$ read in each of these accounts of girls "treated like an indentured servant, forc[ed] to do all the cooking, cleaning, and babysitting,", 23 "condemned to a life of virtual

118 In re Marriage of Wang, 896 P.2d 450, 451-52 (Mont. 1995) (Leaphart, J., dissenting).

119 Id. at 454.

${ }^{120}$ Elissa Wall \& Lisa Pulitzer, Stolen InNOCENCE: My Story of GRowing UP in a Polygamous Sect, Becoming a TeEnage Bride, and Breaking Free of WarRen JEFFS 126, 419-20 (2008).

${ }^{121}$ CAROLYN JeSSOP \& LAURA PALMER, ESCAPE 385 (2007).

122 ANDREA MOORE-EMMETT, GOD'S BROTHEL: THE EXTORTION OF SEX FOR SALVATION IN CONTEMPORARY MORMON AND CHRISTIAN FUNDAMENTALIST POLYGAMY AND THE STORIES OF 18 WOMEN WHO ESCAPED 16 (2004).

${ }^{123}$ JESSOP \& PALMER, supra note 121, at 53. 
slavery," 124 and taught that "“[a] woman's role is to be obedient without question to her husband" "125 and that "[a] woman had no right to speak out ... even if [her] goal was [to] protect[] her daughter."126 These women write, not only of being denied education they specifically longed for and requested, ${ }^{127}$ but of receiving education, not only in the home, but in FLDS controlled classrooms, into complete submission to the brutality young boys are simultaneously encouraged to perpetrate upon them. ${ }^{128}$ Thus, for example, according to Carolyn Jessop, Warren Jeffs, who served as a teacher at the FLDS school before he succeeded his father Rulon as the community's Prophet,

brought one of his wives into the auditorium, which was packed with boys. [She] had a long braid that fell past her knees. Warren grabbed the braid and twisted and twisted it until she was on her knees and he was ripping hair from her head. He told the boys that this was how obedient their wives had to be to them. ${ }^{129}$

These autobiographical accounts also give the lie to the FLDS claim that the state of Texas's seizure of the children was uniquely disruptive to the otherwise stable and secure home life the FLDS children had always known. ${ }^{130}$ Their authors tell of home life in the community repeatedly disrupted by order of the Prophet, who expelled boys and men from the community, ${ }^{131}$ reassigned the men's wives and children to other men in other households, frequently moved family members between and among enclaves in Texas, the Colorado/Utah border, and Canada, and

\footnotetext{
${ }^{124}$. MOORE-EMMETT, supra note 122 , at 93.

${ }^{125}$ WALL \& PULITZER, supra note 120 , at 188 (quoting a conversation with Warren Jeffs).

${ }^{126}$ JESSOP \& PALMER, supra note 121, at 52.

${ }^{127}$ See, e.g., JESSOP \& PALMER, supra note 121, at 32 (noting FLDS girls' strong desire to attend school); MOORE-EMMETT, supra note 122, at 50 (noting that "thousands of polygamous children are deprived of this basic right either by being removed from school at a young age or receiving an education lacking in quality").

128 JESSOP \& PALMER, supra note 121, at 37, 195.

${ }^{129}$ Id. at 195 .

${ }^{130}$ See, e.g., MOORE-EMmETt, supra note 122, at 94 (recounting how, "[f]or Laura, there were no options living in a community that demands unquestioning allegiance and obedience to all men. It is a community that preaches, 'You can all but kill a child for deliberately disobeying.' There were no options when prayer is the only solution to your problems, when you do not know you can call 911 , and when your mother is powerless to protect you from beating inflicted by the other mothers or from sexual assault by your father and brothers").

${ }^{131}$ See, e.g., id. at 50 (stating that " $\left.\mathrm{t}\right] \mathrm{h}$ he treatment boys receive often depends on family connections and ability to conform. As boys very often present competition for older men seeking marriageable girls, they are driven away to fend for themselves, stay. to become the worker bees of the groups or they die mysteriously").
} 
then occasionally welcomed back those he had previously expelled from the community. ${ }^{132}$

Unfortunately, however, so long as so many judges continue to underestimate the harm even extremely sexist parents such as those of the FLDS can do, and to undervalue the voices for women's equality raised against those parents, by, among others, some of their ex-wives and mothers of their children, our legal system will have failed to live up to its constitutional commitment to offer all persons, including the girls and boys whose education, adoption and custody the state regulates, the equal protection of the laws.

${ }^{132}$ WALL \& PULITZER, supra note 120 , at 18 ; see, e.g., id. at 89-91, 117-18 198-99 (discussing how the author's father lost his priesthood and part of his family-only part because one of his wives refused to follow Jeffs' command to leave her husband-but was later welcomed back into full membership in the community, "rebaptized into the priesthood," and invited to join the move to Colorado City). 